\title{
Adrenal Insufficiency Caused by Bilateral Adrenal Metastases - a Rare Treatable Cause for Recurrent Nausea and Vomiting in Metastatic Breast Cancer
}

\author{
Claudia Bausewein Robert Kühnbach Birgit Haberland \\ Interdisziplinäres Zentrum für Palliativmedizin, Klinikum der Universität München, Germany
}

\section{Key Words}

Nausea - Vomiting · Breast cancer, metastatic ·

Metastases, adrenal · Insufficiency, adrenal

\section{Summary}

Background: Nausea and vomiting are common symptoms in patients with malignant disease. Several, sometimes rare causes have to be considered to decide the right treatment. Case Report: We report of a patient suffering from advanced breast cancer and complaining of severe nausea and vomiting over several weeks without any successful treatment. Later on, she developed marked hyperpigmentation of the skin and hypo-osmolar dehydration. Adrenal enlargement was noted in an abdominal scan. The suspected diagnosis of primary adrenocortical insufficiency due to metastases was confirmed by laboratory tests. After replacement therapy with hydrocortisone and fludrocortisone, the general condition of the patient improved dramatically and the symptoms of nausea and vomiting disappeared completely. Conclusion: If a patient with advanced cancer presents with unexplained and protracted nausea, vomiting and weakness, particularly if accompanied by hyponatremia and normal potassium levels, adrenal insufficiency due to adrenal metastases should be considered.

\section{Introduction}

Nausea and vomiting are common symptoms in patients with advanced metastatic malignancy [1]. There are several causes for nausea and vomiting, mainly gastrointestinal, metabolic,

\section{Schlüsselwörter}

Übelkeit · Erbrechen · Brustkrebs, metastasierter . Nebennierenmetastasen · Nebennierenrindeninsuffizienz

\section{Zusammenfassung}

Hintergrund: Übelkeit und Erbrechen sind häufige Symptome bei Patienten mit fortgeschrittenen Tumorerkrankungen. Verschiedene, manchmal seltene Ursachen müssen bedacht werden, bevor die richtige Therapie gewählt werden kann. Fallbericht: Wir berichten über eine Patientin mit fortgeschrittenem metastasiertem Mammakarzinom, die über mehrere Wochen unter therapieresistenter Übelkeit und Erbrechen litt. Später entwickelte sie eine deutliche Hyperpigmentierung der Haut und eine hypoosmolare Dehydratation. In der computertomographischen Untersuchung des Abdomens war eine Vergrößerung der Nebennieren zu sehen. Die Verdachtsdiagnose einer Nebenniereninsuffizienz aufgrund von Nebennierenmetastasen wurde durch Labortests bestätigt. Unter Substitutionstherapie mit Hydrocortison und Fludrocortison verbesserte sich der Allgemeinzustand der Patientin dramatisch, Übelkeit und Erbrechen verschwanden komplett. Schlussfolgerung: Eine Nebenniereninsuffizienz sollte bei Patienten mit einer fortgeschrittenen Tumorerkrankung und ungeklärter und protrahierter Übelkeit, Erbrechen und Schwäche, besonders in Verbindung mit einer Hyponatriämie und normalen Kaliumwerten, vermutet werden.

toxic, cerebral and psychological [2]. However, some rare causes of nausea and vomiting can easily be overlooked, with the consequence that adequate treatment will not be provided. We report of a 75-year-old lady suffering from profuse nausea and vomiting.

\begin{tabular}{|c|c|}
\hline KARGER & (c) 2006 S. Karger GmbH, Freiburg \\
\hline $\begin{array}{l}\text { Fax +497614520714 } \\
\text { E-mail Information@Karger.de } \\
\text { www.karger.com }\end{array}$ & $\begin{array}{l}\text { Accessible online at: } \\
\text { www.karger.com/onk }\end{array}$ \\
\hline
\end{tabular}




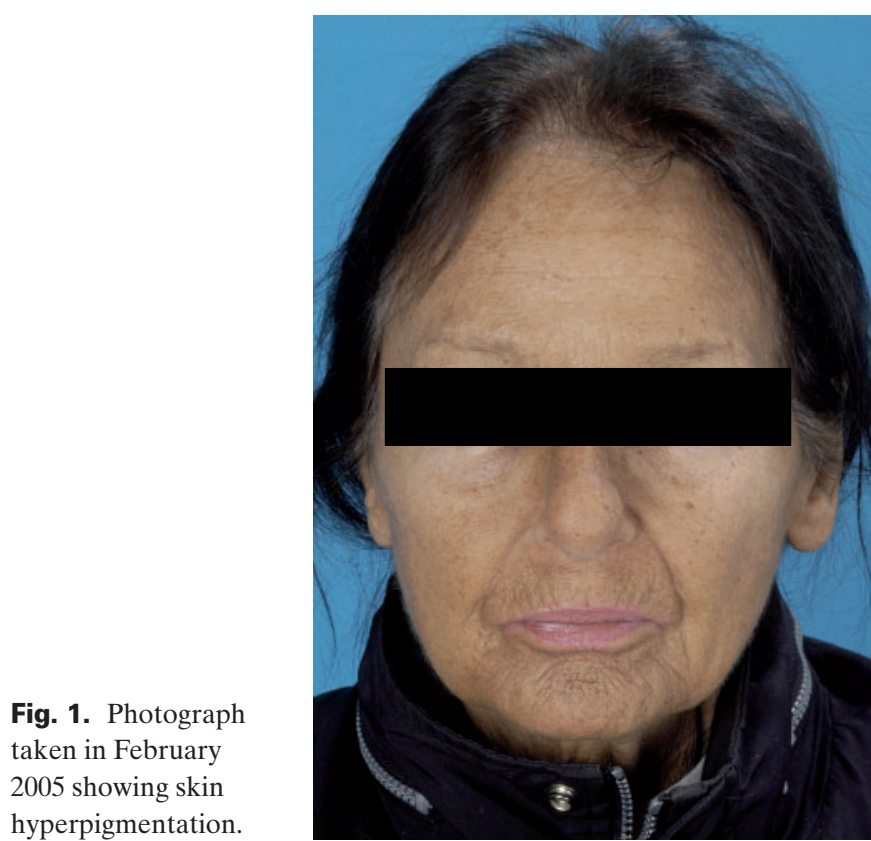

hyperpigmentation.
Fig. 2. Abdominal CT scan showing bilateral adrenal metastases (arrows). hyperpigmentation.

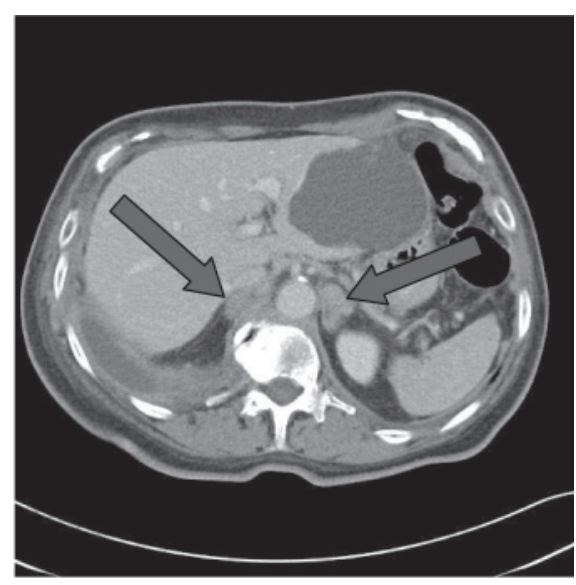

\section{Case Report}

A 75-year-old lady with metastatic breast cancer and known bone metastases was admitted to our palliative care unit in February 2005 with persistent nausea, profuse vomiting and signs of dehydration. After breast surgery in 1996, she had received adjuvant chemotherapy and radiotherapy. In summer 2004, she had received oral cyclophosphamide for several months to treat newly developed bone metastases. On admission, we saw a very ill lady with marked weakness, who needed support to leave her bed. On physical examination, she presented with low blood pressure $(85 / 65 \mathrm{~mm} \mathrm{Hg})$, marked dehydration and hyperpigmentation of the skin, predominantly in the face (fig. 1). The patient had noticed a change in her skin color for several months.

In November 2004, she had been admitted to a department of gastroenterology where she had presented with profuse nausea and vomiting for the first time. At that time, low blood pressure $(110 / 70 \mathrm{~mm} \mathrm{Hg})$ and dehydration were the only remarkable signs on physical examination. The relevant laboratory findings are shown in table 1 . Computed tomography (CT) examination of the brain, gastroscopy and abdominal ultrasound showed no relevant abnormalities. The chest X-ray showed a marked right-sided pleural effusion. The patient recovered after rehydration and antiemetic therapy with metoclopramide and was discharged. In January 2005, the patient was re-admitted to the hospital, again complaining of nausea and severe vomiting. She had not taken antiemetics at home as they did not help. This time, she presented in bad general physical condition with exhaustion, weakness and dizziness. Her blood pressure was $85 / 65 \mathrm{~mm} \mathrm{Hg}$. Physical examination was without pathological findings, except for reduced respiratory sounds over the right lung. The relevant laboratory findings are shown in table 1 . The brain CT scan was repeated without showing new results. A CT scan of the thorax showed the known pleural effusion and pathological tissue below the carina and in proximity of the right bronchus. An abdominal CT scan showed a liver cyst in the left lobe, plump adrenal glands and widespread bone metastases (fig. 2). The patient was again rehydrated and treated with metoclopramide. After 2 weeks, her condition improved and she was discharged.

The laboratory findings in February 2005 showed hypo-osmolar dehydration with severe hyponatremia but relatively high potassium levels despite continuous vomiting (table 1). These findings, together with the adrenal enlargement noted on the abdominal CT scan, suggested a diagnosis of

adrenal metastases causing primary adrenocortical insufficiency. To confirm the diagnosis, the basal serum cortisol levels were measured which were close to the lower limit of the normal range, while the level of adrenocorticotropic hormone (ACTH) was elevated 60-fold. An ACTH stimulation test failed to show a rise in serum cortisol levels (table 1). The patient was initially treated with intravenous hydrocortisone $200 \mathrm{mg}$, followed by oral hydrocortisone $20 \mathrm{mg}$ daily and fludrocortisone $0.1 \mathrm{mg}$ daily. The general condition of the patient improved dramatically within days, and the symptoms of nausea and vomiting disappeared completely.

\section{Discussion}

Adrenal metastases are not often detected in metastatic cancer. In a recent study from Hong Kong, the prevalence of adrenal metastases at post-mortem examination, adrenalectomy and fine needle aspiration biopsy in 464 cancer patients was $3.1 \%$ [3]. The main primary cancers metastasizing into the adrenal glands were lung cancer $(35.4 \%)$ and gastrointestinal cancers (stomach $14.3 \%$, esophagus $12.1 \%$, liver/bile ducts $10.7 \%$ ). In this study, breast malignancy was the primary site in only $2.9 \%$ of cases.

Corresponding with the low incidence of adrenal metastases, clinical findings of adrenal insufficiency confirmed by laboratory tests have been reported only infrequently in cancer patients. In addition, the prevalence of adrenal insufficiency appears low even in patients with bilateral adrenal metastases [4]. Less than 100 cases of confirmed adrenal insufficiency due to local metastases have been published [3], only a few of which concerned breast cancer patients. Davi et al. [5] reported of a patient in whom adrenal involvement became clinically evident 20 years after radical mastectomy as the only secondary localization of the tumor. Sheeler et al. [6] presented 4 cases ( 1 breast cancer) where adrenal insufficiency was diagnosed at the time of the initial diagnosis of the tumor or at occurrence of first metastases. However, adrenal insufficiency is quite common in patients with breast cancer who are treated with medroxyprogesterone acetate or megestrol acetate. Both drugs have cortisol-like effects with subsequent suppression at the hypothalamic level. In these patients, ACTH levels are low 


\begin{tabular}{llll}
\hline Clinical chemistry (normal levels) & \multicolumn{2}{l}{ Laboratory results } \\
\cline { 2 - 4 } & $\begin{array}{l}\text { 6th December } \\
2004\end{array}$ & $\begin{array}{l}\text { 4th January } \\
2005\end{array}$ & $\begin{array}{l}\text { 10/11th Fe- } \\
\text { bruary } 2005\end{array}$ \\
\hline Sodium, mmol/l $(135-145 \mathrm{mmol} / \mathrm{l})$ & 130.0 & 125.0 & 113.0 \\
Potassium, mmol/ $(3.5-5.0 \mathrm{mmol} / \mathrm{l})$ & 4.7 & 5.0 & 5.0 \\
Calcium, $\mathrm{mmol} / \mathrm{l}(2.05-2.65 \mathrm{mmol} / \mathrm{l})$ & 2.43 & 2.51 & 2.36 \\
Glucose, $\mathrm{mmol} / \mathrm{l}(3.88-6.38 \mathrm{mmol} / \mathrm{l})$ & 4.93 & 4.38 & 2.55 \\
Plasma cortisol, basal, $\mathrm{mg} / \mathrm{dl}(5-25 \mu \mathrm{g} / \mathrm{dl})$ & & & 5.4 \\
Plasma cortisol after ACTH stimulation, $\mu \mathrm{g} / \mathrm{dl}$ & & 5.7 \\
$\quad(\mathrm{more}$ than double the basal level) & & & $>1,499$ \\
ACTH, $\mathrm{pg} / \mathrm{ml}(10-50 \mathrm{pg} / \mathrm{ml})$ & & & \\
\hline
\end{tabular}

[7]. On the other hand, adrenal insufficiency is often suspected in cancer patients as fatigue, weakness, nausea and vomiting are common symptoms in advanced stages. Cedermark et al. [8] evaluated the adrenal activity of 39 patients with disseminated carcinoma but without metastases to the adrenal glands. Of those, 15 patients showed clinical signs and symptoms of adrenal insufficiency. However, cortisol secretion was found to be increased rather than decreased in these patients, probably due to stress. The authors concluded that symptoms resembling adrenal insufficiency in cancer patients are not usually associated with decreased cortisol secretion.

In conclusion, if a patient with advanced cancer presents with unexplained and protracted nausea, vomiting and weakness, adrenal insufficiency should be considered, particularly if accompanied by hyponatremia and normal potassium levels. Our patient had been suffering from severe nausea and vomiting together with fatigue and adynamia for over 3 months.
After exclusion of the main possible causes, e.g. hepatomegaly, brain metastases, hypercalcemia or drug side effects, primary adrenal insufficiency due to bilateral adrenal metastases was found to be the cause of the symptoms. We did not confirm the diagnosis histologically, as it would not have had any consequence. Therefore, it remains unclear whether the metastases were caused by the breast cancer or possibly lung cancer which could be suspected in connection with the findings of the chest CT scan. Lastly, treatment of adrenal insufficiency in patients with metastatic malignant disease greatly increases quality of life and improves life expectancy.

\section{Acknowledgement}

We are grateful to Prof. Gian Domenico Borasio for his comments in preparing this case report.

\section{References}

1 Potter J, Higginson I: Frequency and severity of gastrointestinal symptoms in advanced cancer; in Bruera E (ed): Gastrointestinal Symptoms in Advanced Cancer Patients. Oxford, Oxford University Press, 2002, pp 1-15.

2 Mannix KA: Palliation of nausea and vomiting; in Doyle D, Hanks G, Cherny N, Calman K (eds) Oxford Textbook of Palliative Medicine. Oxford, Oxford University Press, 2004, pp 459-468.

3 Lam KY, Lo CY: Metastatic tumours of the adrenal glands: a 30-year experience in a teaching hospital. Clin Endocrinol 2002;56:95-101.
4 Lutz A, Stojkovic M, Schmidt M, Arlt W, Allolio B, Reincke M: Adrenocortical function in patients with macrometastases of the adrenal gland. Eur J Endocrinol 2000;143:91-97.

5 Davi MV, Francia G, Brazzarola P, Olivieri M, Petrozziello A, Orsolini A, Petronio R, Sussi PL et al: An unusual case of adrenal failure due to isolated metastases of breast cancer. J Endocrinol Invest 1996;19:488-489.
6 Sheeler LR, Myers JH, Eversman JJ, Taylor HC: Adrenal insufficiency secondary to carcinoma metastatic to the adrenal gland. Cancer 1983;52: 1312-1316.

7 Naing KK, Dewar JA, Leese GP: Megestrol acetate therapy and secondary adrenal suppression. Cancer 1999;86:1044-1049.

8 Cedermark BJ, Sjoberg HE: Adrenal activity in patients with advanced carcinomas. Surg Gynecol Obstet 1981;152:461-465. 